Article

\title{
Diurnal Variation of Rainfall in a Tropical Coastal Region with Complex Orography
}

\author{
Martha Pérez-Méndez ${ }^{1, *}$, Adalberto Tejeda-Martínez ${ }^{1}$ and David R. Fitzjarrald ${ }^{2}$ \\ 1 Grupo de Climatología Aplicada, Universidad Veracruzana, Xalapa-Enríquez, Veracruz 91090, Mexico; \\ atejeda.martinez@gmail.com \\ 2 Atmospheric Sciences Research Center, University at Albany, SUNY, Albany, NY 12203, USA; \\ dfitzjarrald@albany.edu \\ * Correspondence: pmendez.martha@gmail.com
}

Received: 16 August 2019; Accepted: 13 September 2019; Published: 7 October 2019

check for updates

\begin{abstract}
We examined the diurnal cycle of the rainfall in a coastal tropical mountainous region in central Veracruz State, Mexico $\left(18^{\circ}-21^{\circ} \mathrm{N}, 95.5^{\circ}-98.5^{\circ} \mathrm{W}\right)$, featuring a striking topographic gradient running from sea level at the Gulf of Mexico coast to $5000 \mathrm{~m}$ above sea level (m.a.s.l.) in less than $100 \mathrm{~km}$ horizontal distance. During the summer, this unique location leads to regular the interaction between the easterly moisture inflow and the mountainous barrier. Over the complex terrain, forced ascent leads the occurrence of maximum rainfall during the afternoon (16-19 local time, LT $\approx 1 \frac{1}{2}$ hours ahead of solar time in summer), first along the slope and later over the coast. Along the coastal plain, the precipitation continues until the early morning consistent with there being convergence between land breezes and the trade winds. Observations obtained during a measurement campaign from 28 June to 3 July 2015, indicate that during the early evening downslope winds move against easterly flow, likely due to katabatic outflows previously observed over the region. These features are confirmed using spatial $\left(0.88^{\circ}\right)$ and temporal $(30 \mathrm{~min})$ resolution $\mathrm{CMORPH}$ rainfall estimates, since we observed evening episodes initiating along the slope during the afternoon (14-17 LT) moving later towards the coast.
\end{abstract}

Keywords: complex coastal topography; diurnal rainfall cycle; interacting local/regional wind systems

\section{Introduction}

Especially in the tropics, repeated weather conditions allow topographic effects and local breeze circulations largely to determine the mesoscale spatial and temporal variability of the rainfall diurnal cycle [1-11]. Characterizing this variability is crucial to understand the surface-atmosphere interaction within the climate system, and thereby, can be used to improve the assessment of climate model results [12-15].

The land-sea breeze system is forced by the warming differences between the continent and the ocean, but other details are determined by factors as shoreline curvature, latitude, atmospheric stability and synoptic patterns, as well as the effect of the interaction between mountainous terrain and this local-scale circulation $[1,7,11,16-23]$.

In previous studies, the diurnal cycle of the rainfall has been found to be mainly influenced by local wind patterns, as sea and mountain breezes, and local topographical features [20]. For example, over Taiwan the rainfall in summer is greater during the afternoon than in the morning due to the contribution of orographically-induced rainfall [18]; over the island of New Guinea winds associated with the sea breeze rise at the foot of the mountains and allow the initiation of afternoon convection [13]. A similar phenomenon occurs in a region of Tibet, where higher rainfall is observed during the afternoon in mountainous regions [24]. 
This study focuses on the central part of the Gulf of Mexico watershed along the shores and mountain ranges of the state of Veracruz (Figure 1a). Here, the Sierra Madre Oriental (SMO), Sierra Madre del Sur (SMS), and Trans-Mexican Volcanic Belt (TMVB) join (Figure 1a) and is characterized by complex topography dominated by two important mountains: the Cofre de Perote (4200 m.a.s.l.) and the Pico de Orizaba (at 5600 m.a.s.l., the highest point in Mexico; Figure 1a). At this point, a protruding headland at roughly $19.7^{\circ} \mathrm{N}, 96.5^{\circ} \mathrm{W}$ divides the coastal plain into: (a) the Northern Veracruz Littoral (NVL), bounded by the Sierra Madre Oriental (SMO) and associated watersheds draining to the northeast; and (b) its counterpart, the Southern Veracruz Littoral (SVL), bounded by the Sierra Madre del Sur (SMS) and corresponding watersheds draining to the southeast. Moreover, both coastal plains facing the Gulf of Mexico feature low hills (Figure 1a). Here, we consider the coastal plains to be in elevations between 0 and 500 m.a.s.l., from 500 to 2000 m.a.s.l. are the slopes with the top of the slope merging into a plateau at approximately 2000 m.a.s.l. (Figure 1a). From the coast towards the highest point in the region (Pico de Orizaba) the altitudinal gradient is striking, rising from sea level to 5000 m.a.s.l. in less than $100 \mathrm{~km}$ horizontal distance (Figure 1b). These topographical characteristics and the location embedded at the western end of a Trade Wind circulation during northern summer, make this region a unique natural laboratory for studying the atmospheric processes that link atmospheric surface layer, atmospheric boundary layer, and their coupling with the large-scale circulation.

Studies based on scattered climatological information [25-29] show that during the summer, the interaction among trade winds and the mountainous barriers leads to maximum rainfall over the slopes of the mountain ranges in the central portion of Veracruz State, Mexico. Tejeda et al. [29] reported that the trade winds are modified by the complex terrain and the $90 \%$ of the vertical motions are due to convection forced by topographic effects. Through case studies, Fitzjarrald [30] showed an important feature of the region, that is the presence katabatic wind in summer during the afternoon in central Veracruz State. This downslope motion prevails counter to easterly flow, reaching the plains in the night. Both analysis over the slopes and coastal areas support the important role of the sharp terrain on the regional climate.

This study complements the previous findings, providing detailed description of the diurnal cycle of precipitation. The hypothesis is that the exaggerated topographic gradient nearly normal to the steady trade influences the timing and location of summer rainfall in the region. That is, we seek to understand how the combination the easterly winds with the breeze system along with mountainous barriers, determines the altitude of the rainfall initiation and propagation in otherwise undisturbed conditions. The CMORPH (3-h and $0.25^{\circ}$ resolution temporal and spatial, respectively) averaged over 1998-2015 is used to obtain the hourly mean precipitation. Moreover, cases are analyzed using high spatial and temporal resolution CMORPH (30-minute and $0.088^{\circ}$ resolution temporal and spatial, respectively) to show that some rainfall events present a distinct behavior with respect to the mean conditions.

Section 2 of this paper discusses the data used in this study. Section 3 presents a climatology for the central Veracruz Coastal Zone (VCZ), providing an overview of the summertime rainfall regime and wind patterns. The diurnal mean rainfall and wind patterns are described in Section 4. In Section 5, we present a case studies of the diurnal rainfall cycle and associated local circulations in the central VCZ region. 

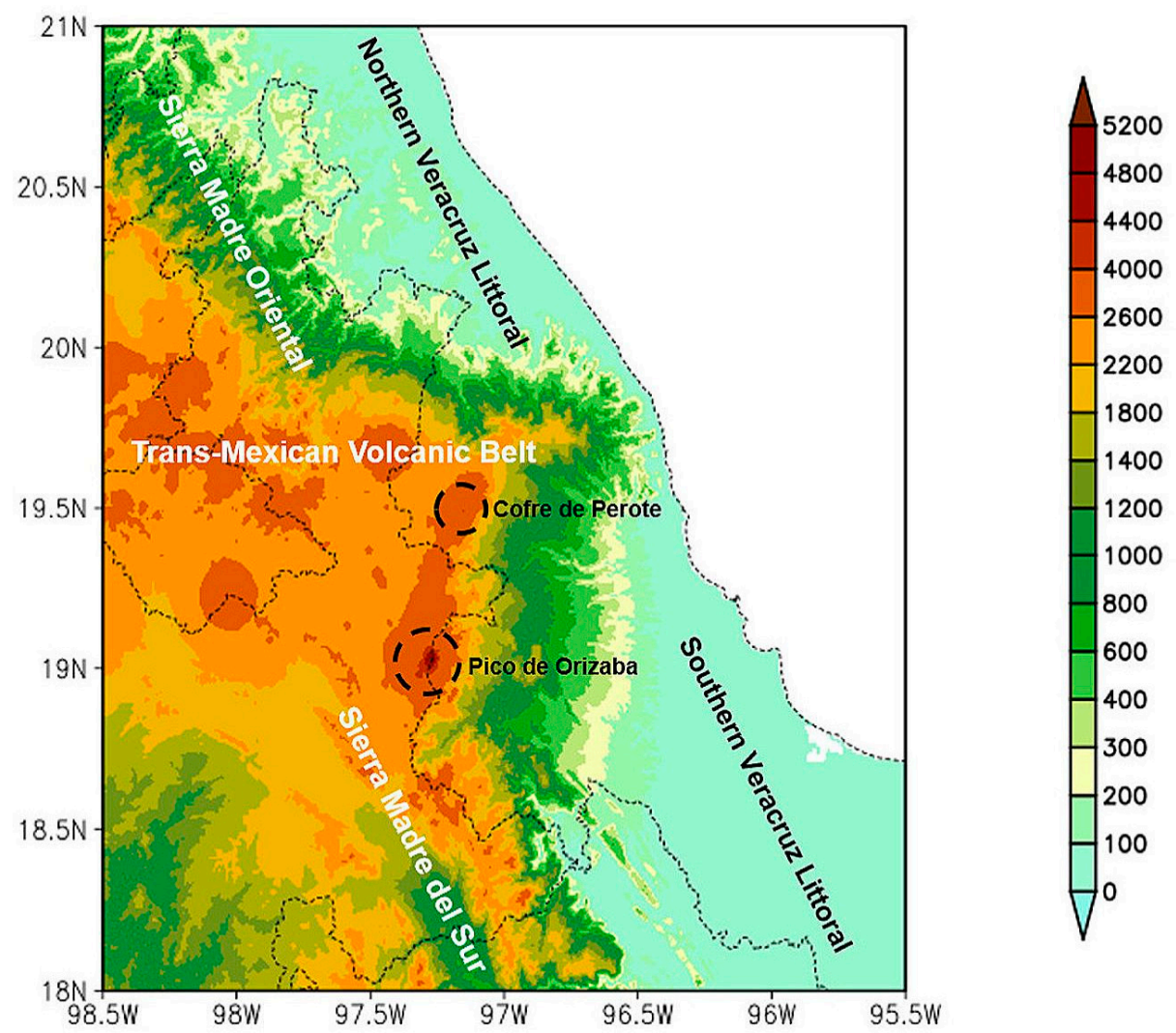

(a)

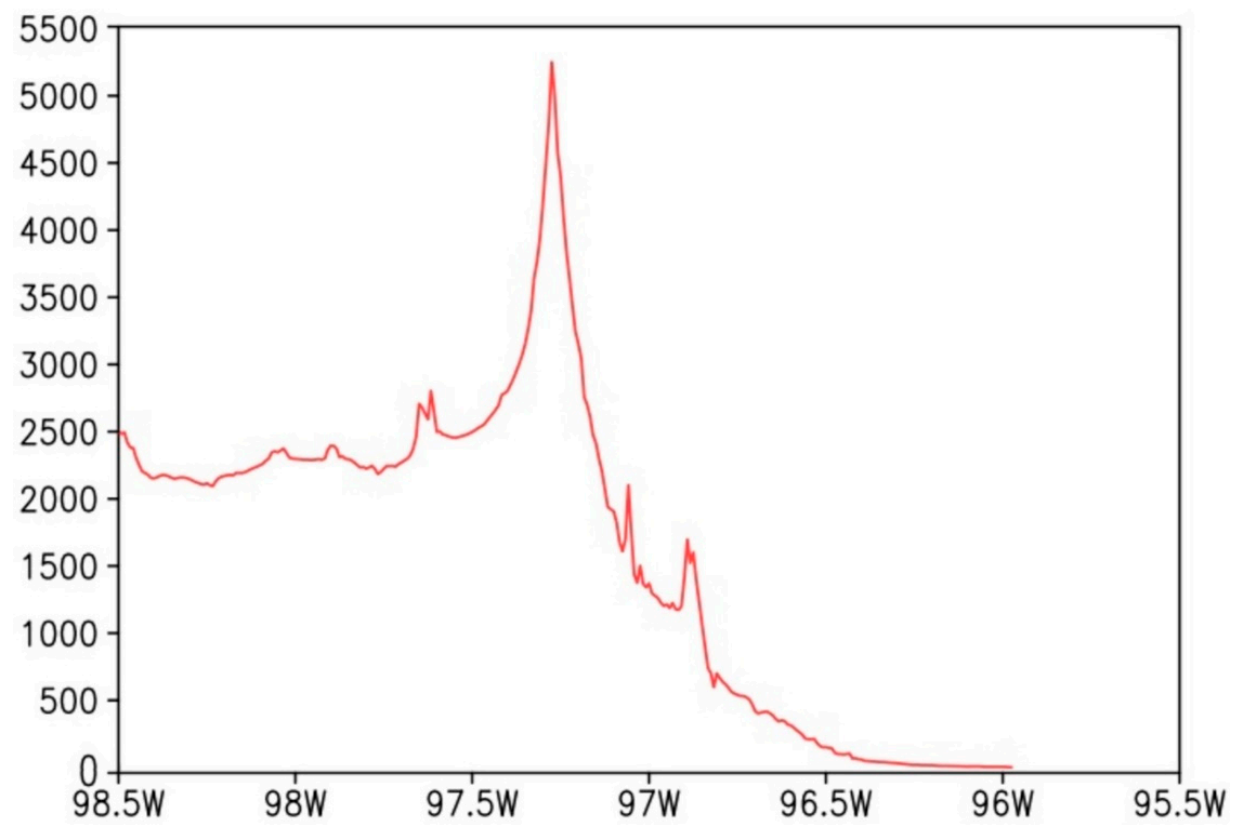

(b)

Figure 1. (a) Topography of the region VCZ (see text for further explanation); and (b) cross-section of the topography on $19^{\circ} \mathrm{N}$. The same scale of values in meters above sea level (m.a.s.l.) in both figures. 


\section{Data and Methods}

\subsection{Observed Data}

Currently, objective reanalysis of atmospheric and land surface hydrology dataset based on observations can supply useful information, especially in regions where observations data are scarce and there may be large gaps in time series. However, the liberal use of interpolation in this approach makes it important to consider the uncertainty of the spatial and temporal patterns of the variables represented. Sometimes, it is essential to perform special measurement campaigns designed to examine local-scale details unresolved in the reanalysis dataset. For this reason, measurements of wind speed and wind direction were obtained in the VCZ (Figure 1a) during a field campaign performed from 28 June to 3 July 2015. Additional datasets introduced to complement the analysis of the surface conditions (Table 1) are identified in Figure 2.

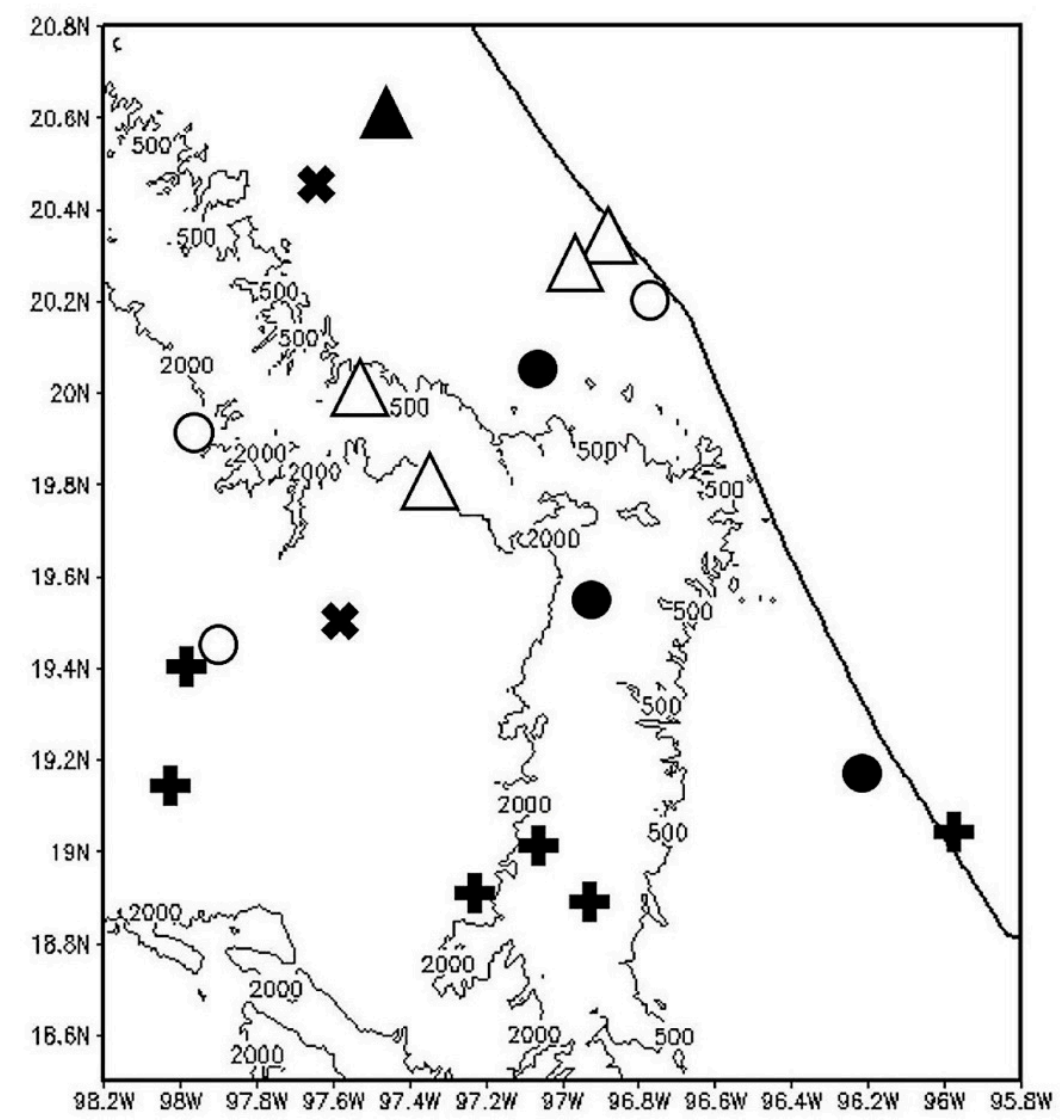

Figure 2. Measurement sites. Mexican National Weather Service automatic weather stations (+), Institute of Geography of the UNAM stations (open circles), Universidad Veracruzana stations (closed circles), measurement points during the summer campaign (open triangles), METAR stations (closed triangles), and Weather Underground cited stations (x). See Table 1. The contours of 500 and 2000 m.a.s.l. are shown. 
Table 1. Additional sources of meteorological observations of wind speed and direction.

\begin{tabular}{ccc}
\hline Source & Instrumentation & No. Stations \\
\hline $\begin{array}{c}\text { Mexican National Weather Service automatic } \\
\text { weather stations }\end{array}$ & $\begin{array}{c}\text { http://smn.cna.gob.mx/es/observando-el-tiempo/ } \\
\text { estaciones-meteorologicas-automaticas-ema-s } \\
\text { https:/www.wunderground.com/ } \\
\text { wegional Weather Underground cited stations } \\
\text { Institute of Geography of the UNAM stations }\end{array}$ & 6 \\
Universidad Veracruzana Stations & $\begin{array}{c}\text { Meteorological station Davis Vantage Pro 2. } \\
\text { Termohygrometric datalogger HOBO LCD Onset } \\
\text { Computer Corp, model U14-001. High precision } \\
\text { portable weather station SKYWATCH model } \\
\text { GEOS N }{ }^{\circ} \text { 11. }\end{array}$ & 3 \\
METAR data & Automated Surface Observing System (ASOS). & 3 \\
\hline
\end{tabular}

\subsection{CMORPH Data}

Rainfall data from remote sensors permit a global analysis, facilitating broad view of climatology [6-8,31].

NOAA's Climate Prediction Center (CPC) developed global rainfall estimates with a temporal resolution of 30-min and 3-h and a spatial resolution of $0.088^{\circ}$ and $0.25^{\circ}$. To obtain CMORPH version 1.0 data, CPC has reprocessed the products to cover the period from 1998 until the present. To produce the CMORPH product, rainfall estimates obtained from available passive microwave (PMW) satellites are propagated by motion vectors, derived from observations in the spectral band corresponding to infrared in geostationary satellites. The form and intensity of the rainfall are modified from the morphing technique between each scan performed by the PMW satellites, by a linear interpolation in time [32]. These data have been used in several studies related to the rainfall diurnal cycle $[10,21-23,32]$.

\subsection{NARR Data}

The North American Regional Reanalysis (NARR) dataset is available since 1979. The spatial resolution is 32-km, with 29 vertical levels and three-hourly temporal resolution [33]. The zonal and meridional component of the wind speeds are reported in the NARR, which together with the high spatial and temporal resolution, allows us to assess regional circulation patterns.

\section{Regional Rainfall Climatology}

Relatively high values of rainfall over the VCZ occur from May to October (Figure 3a). These rains are associated with the interaction between moist winds from the Gulf of Mexico and mountainous barriers as well as the presence of tropical cyclones [25-30,34]. Previous studies have reported that the climatological contribution of tropical cyclones (TCs) to mean annual rainfall is relatively minor over the VCZ, between 15-20\% [35-39]. The monthly mean precipitation associated with TCs has been estimated for the region, using TMPA and other remote sensing products (Appendix A). However, Breña-Naranjo [35] found that these values in Mexico are underestimated by up rain $50 \%$ compared to direct observations. A recent study which used global rain gauges [39], reported that in the stations located in the VCZ, the highest contribution of TCs to the mean seasonal rainfall occurs from September to November with values about $37 \mathrm{~mm} \mathrm{mo}^{-1}$ (Figure $3 b$ ).

On the other hand, between November and April the rainfall is mainly associated with the arrival of polar air masses, however, the values are smaller compared to the rainy season (May-October). 


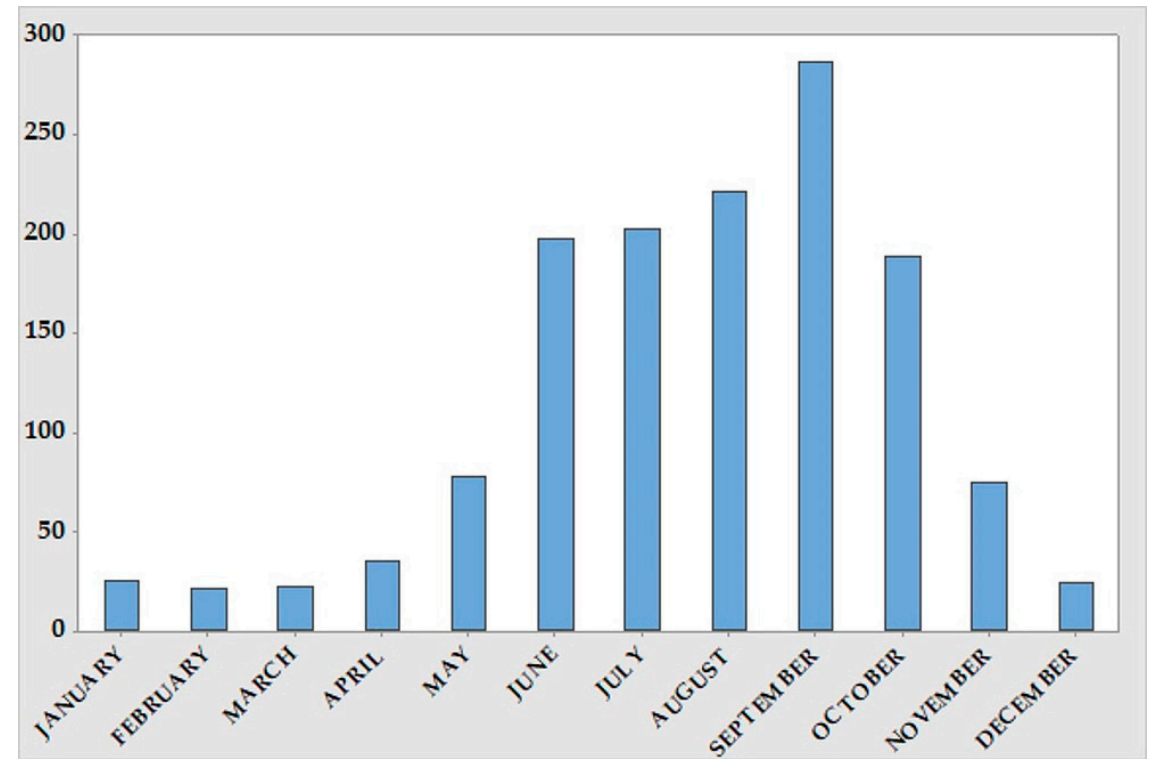

(a)

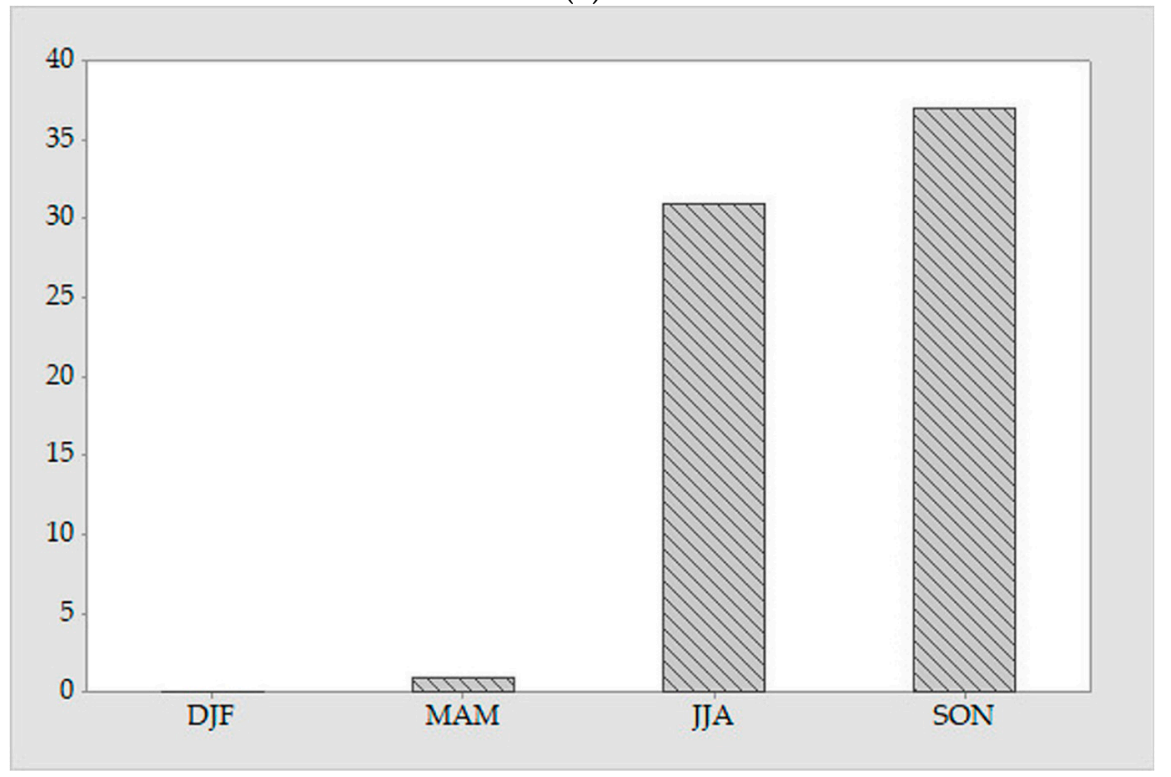

(b)

Figure 3. (a) Monthly mean rainfall $\left(\mathrm{mm} \mathrm{mo}^{-1}\right)$ over VCZ detonated by the square in Figure 5, during 1998-2015 using CMORPH precipitation data (3-h and $0.25^{\circ}$ resolution temporal and spatial, respectively). (b) The estimated contribution of TCs to mean seasonal rainfall $\left(\mathrm{mm} \mathrm{mo}^{-1}\right)$ using global rain gauges data between 1970 and 2014 and modified from Khouakhi et al. [39]. December-January-February (DJF), March-April-May (MAM), June-July-August (JJA), and September-October-November (SON).

During the summer, the subtropical high-pressure belt over the Northern Hemisphere migrates northwards intensifying the trade winds [40] (Figure 4). These winds flow from the southern edge of the Bermuda anticyclone and arrive in the study region as a steady easterly wind. During their journey over the waters of the Gulf of Mexico the trade wind layer moistens, bringing a continuous source of humid air to the continent $[25,28,41]$. As these moist winds ascend the mountain slope over the VCZ, they lead to a maximum in accumulated rainfall from the foothills up to 2000 m.a.s.l. (Figure 5) $[25,27,29]$. 

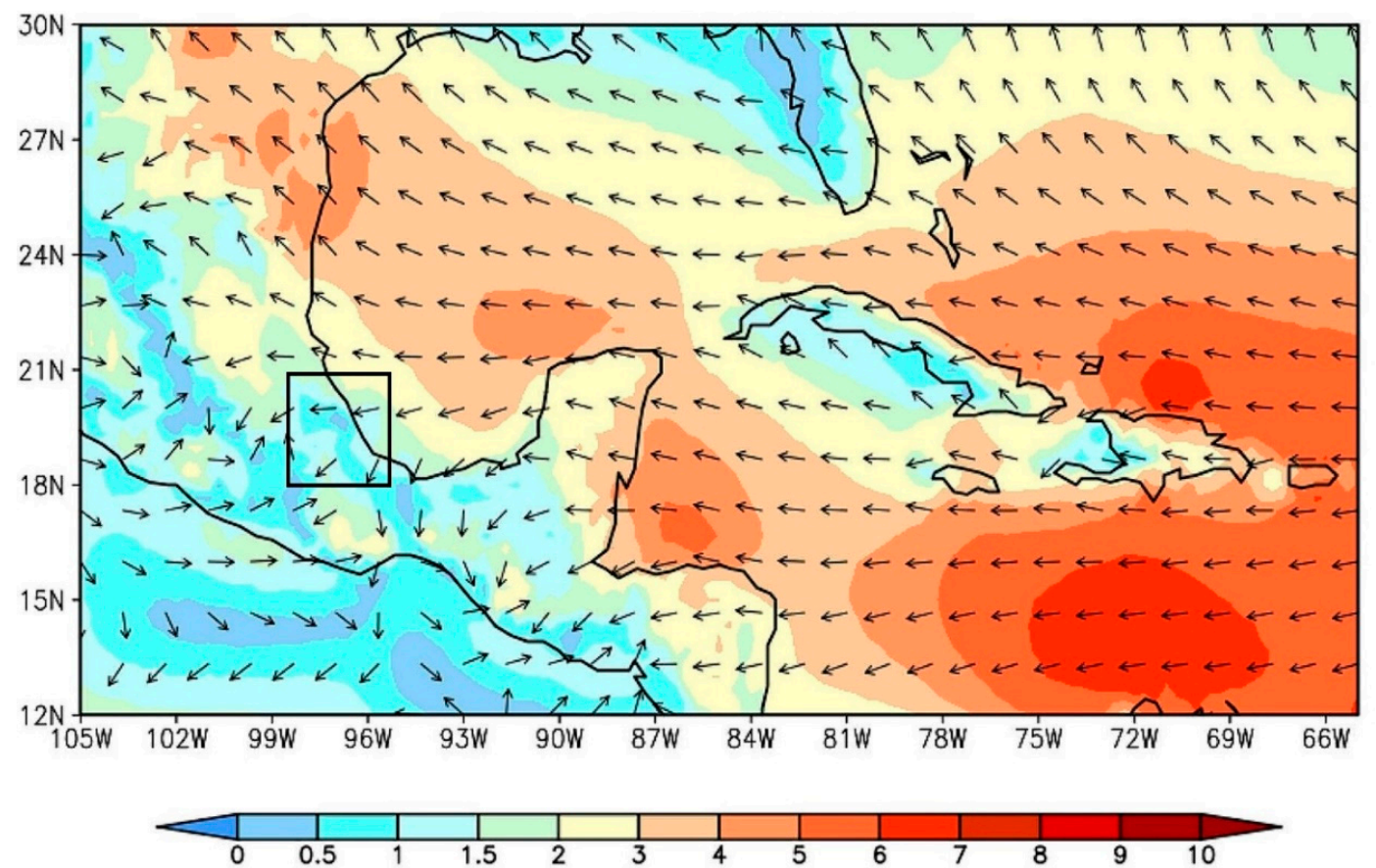

Figure 4. Mean wind field $\left(\mathrm{m} \mathrm{s}^{-1}\right)$ at $10 \mathrm{~m}$ from NARR re-analysis data from 1979-2012 for summer (May-October). The vectors correspond only to the wind direction, the magnitude is indicated by shaded.
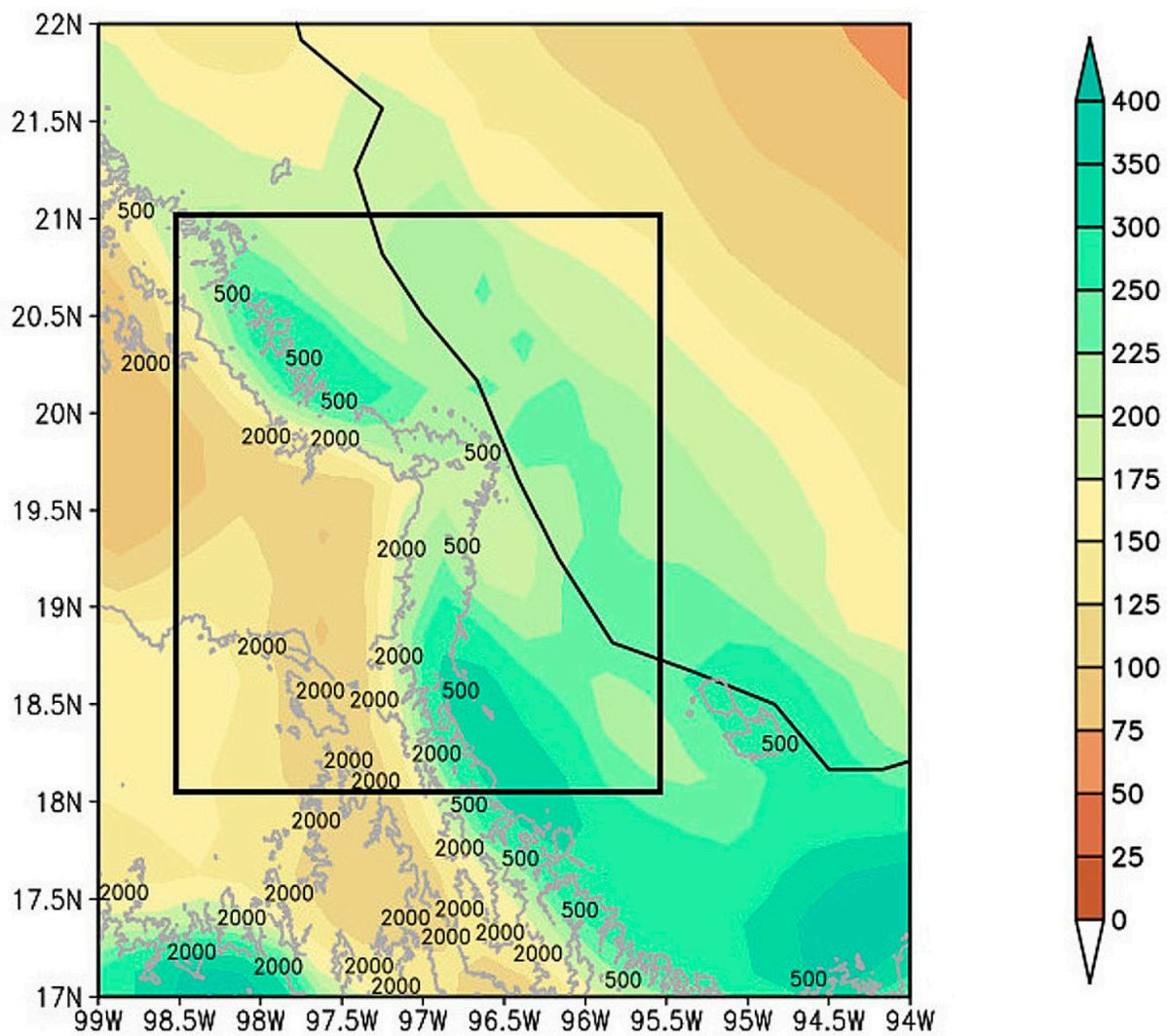

Figure 5. Monthly mean rainfall $\left(\mathrm{mm} \mathrm{mo}^{-1}\right)$ for summer (May to October) from CMORPH data 2015 using a spatial resolution of $2.5^{\circ} \times 2.5^{\circ}$ and considering the period 1998-2015. The contours of 500 and 2000 m.a.s.l. are shown. The square shows the VCZ. 
Near the top of the slope the rainfall values diminish, since in summer the Mexican Altiplano (high plateau) is above the trade inversion. Mosiño and García [28] found that the trade wind inflow from the Gulf of Mexico, enters sporadically into the central Mexican plateau (>2000 m.a.s.1., Figure 1a), being hampered by the mountainous barrier. In satellite images there is a clear distinction between the dry conditions in the Altiplano and a humid climate along the eastern flank of the SMO (e.g., [30]). A similar precipitation regime distinction occurs over a region of the Indochina peninsula, where leeward of mountainous barriers (Dawna mountain range around 1000 m.a.s.1.) the rainfall is diminished compared to the upwind slope [42].

\section{Diurnal Rainfall Cycle along the Coastal Plain}

Between 13 and 19 LT, the easterly flow is observed over the VCZ (Figure 6) and the winds increase in intensity compared to previous hours. In this flow, local-scale winds are also immersed such as the land-sea breeze [29,30]. As these moist Gulf Trade Winds intercept the mountains are subjected to forced ascent, leading in a maximum rainfall along the mountain slopes during the afternoon and early evening (16-19 LT), with mean rainfall values between 18- and 20- $\mathrm{mm} \mathrm{h}^{-1}$ (Figure 7). Such interaction between maritime airflow and mountain ranges is also observed in other tropical regions and it has been concluded that it plays an important role in the initiation of convection $[1,4,7,17,18,22,43]$. The initiation and subsequent precipitation enhancement over the Veracruz littoral occur around the same hours (16-22 LT).

On the other hand, compared to previous hours the rainfall decreases at around 01 LT over the slope of the Sierra to values between 6 - and $8-\mathrm{mm} \mathrm{h}^{-1}$, while in the coastal zone a maximum rainfall of about $16 \mathrm{~mm} \mathrm{~h}^{-1}$ is observed (Figure 7 ). In other regions of the tropics, similar behavior has been reported during the early morning over the coastline $[1,4,7]$.

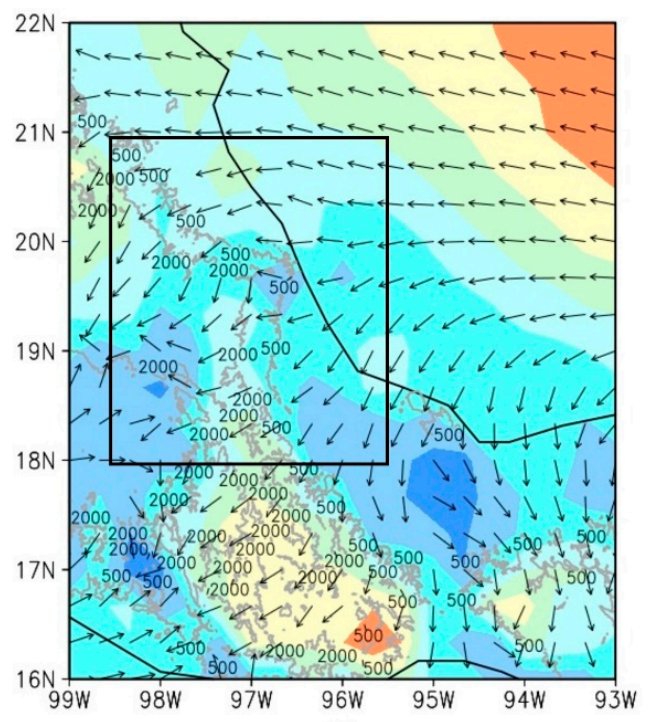

(a)

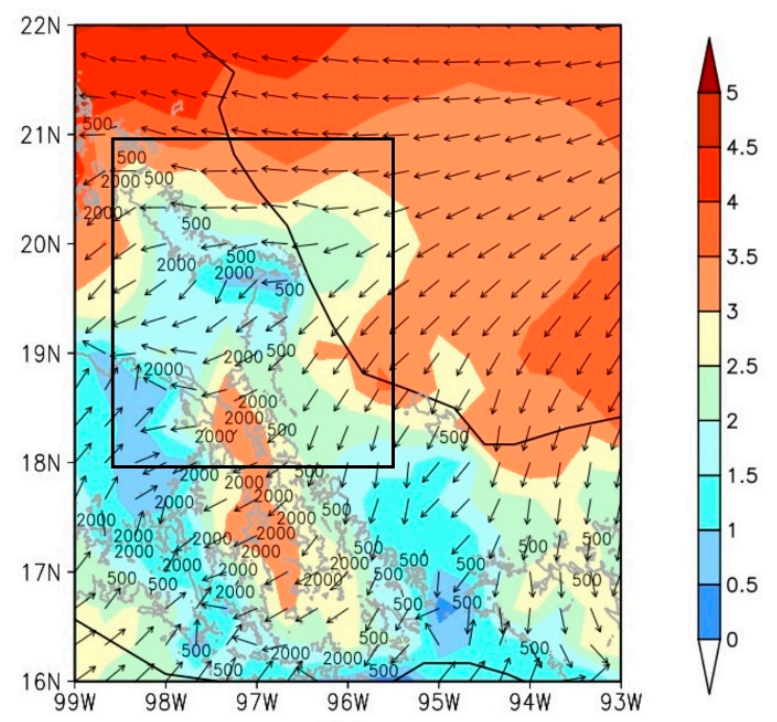

(b)

Figure 6. Average wind field $\left(\mathrm{m} \mathrm{s}^{-1}\right)$ at $10 \mathrm{~m}$ for (a) $13 \mathrm{LT}$ and (b) 19 LT for summer (May-October), using NARR reanalysis data for the period of 1979-2012. For clarity, the vectors correspond only to the wind direction; the magnitude is indicated by shaded. The contours of 500 and 2000 m.a.s.l. are shown. 


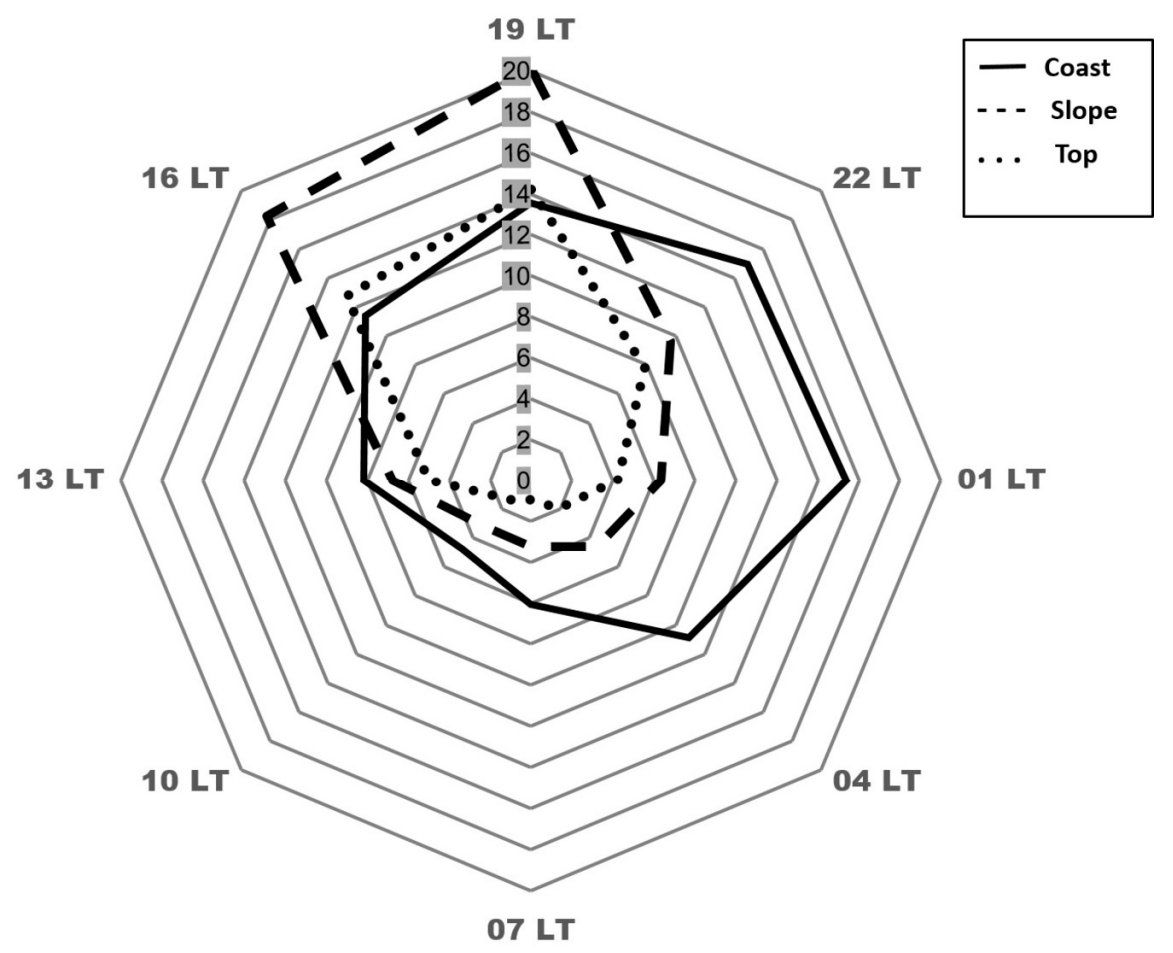

Figure 7. Diurnal variation of precipitation $\left(\mathrm{mm} \mathrm{h}^{-1}\right)$ for the coastal plain (0-500 m.a.s.l.), the slope (500-2000 m.a.s.l.) and the top of the mountains (>2000 m.a.s.l.), using CMORPH precipitation data (1998-2015) for summer (May-October). The inside scale shows the rainfall values and outside scale is the local time.

Between $04 \mathrm{LT}$ and $07 \mathrm{LT}$, the rainfall continues over this coastal region probably due to the convergence between continental winds (land breeze) and the mean trade winds at most part of the coastline (Figure 8). According to Sato et al. [13], similar convergence between the land breeze and the onshore winds occurs in northeastern Australia and allows for the appearance of an early morning convergence zone. Houze et al. [1] and Qian [22], found that the convergence centered on the coastline of the island of Borneo is a product of the interaction between the land breeze and the flow associated with the Asian monsoon. Over tropical Asia, the maximum of rainfall observed at night and early morning over the coast is due to the convergence of the wind coming from the continent as well as a easterly flow [4].

Indeed, over the continent a rainfall maximum occurs around 16-19 LT with a minimum at 10 LT (Figure 9); while in the Gulf of Mexico the maximum is reached between 01-07 LT and a minimum past solar noon (16 LT). In summary, more rainfall is received over the VCZ during the afternoon, while over the Gulf of Mexico this maximum occurs at early morning. This pattern in the diurnal precipitation cycle over the tropics is associated with the energy provided by solar radiation at different hours of day, the topography as well as land-sea breezes and mountain-valley wind [2,4-7,17,21,22]. Moreover, Fitzjarrald [30] using detailed wind and temperature measurements at a point over the mountainous region of the VCZ $\left(19.5^{\circ} \mathrm{N}, 97^{\circ} \mathrm{W}\right)$, showed the development of a katabatic layer which grows from $\approx 30$ to $200 \mathrm{~m}$ between $05 \mathrm{LT}$ and $08 \mathrm{LT}$. It is possible that these winds spread into the Gulf of Mexico, promoting convergence and the initiation or enhancement of precipitation events during the early morning. 


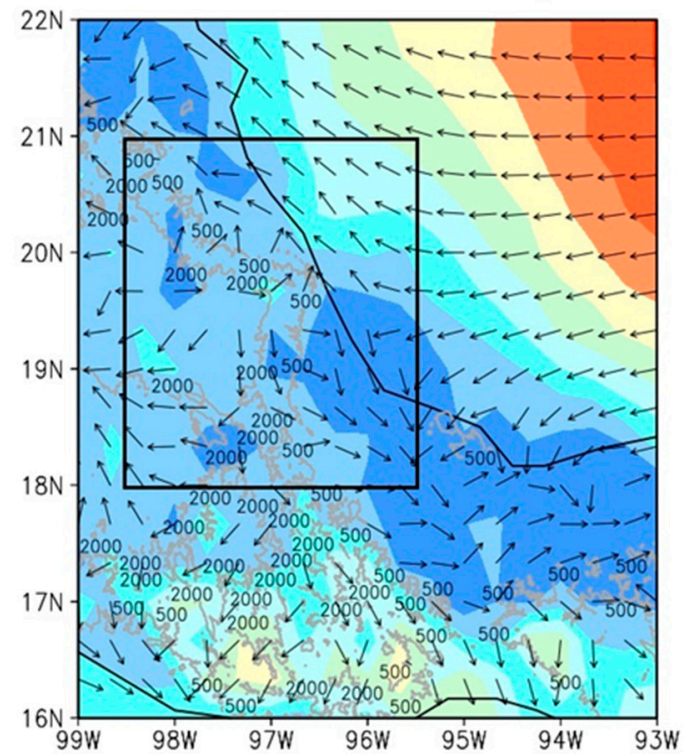

(a)

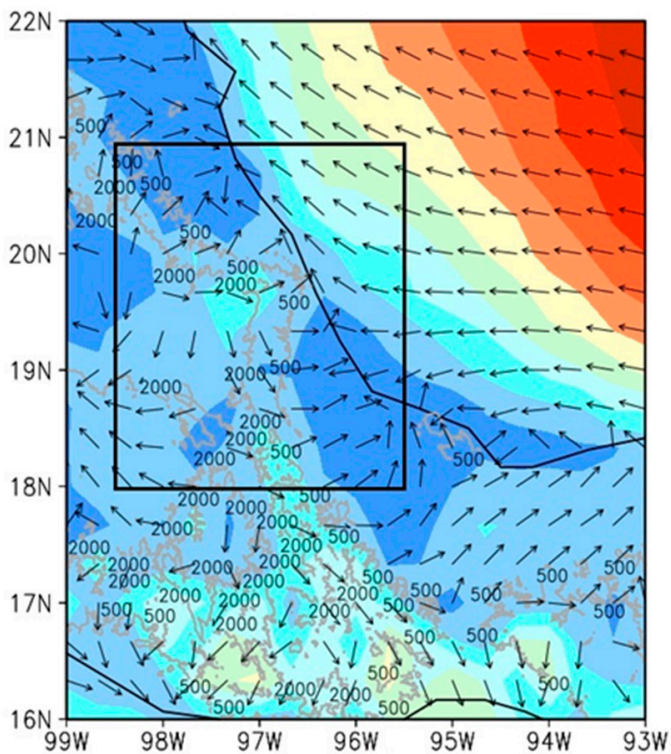

(b)

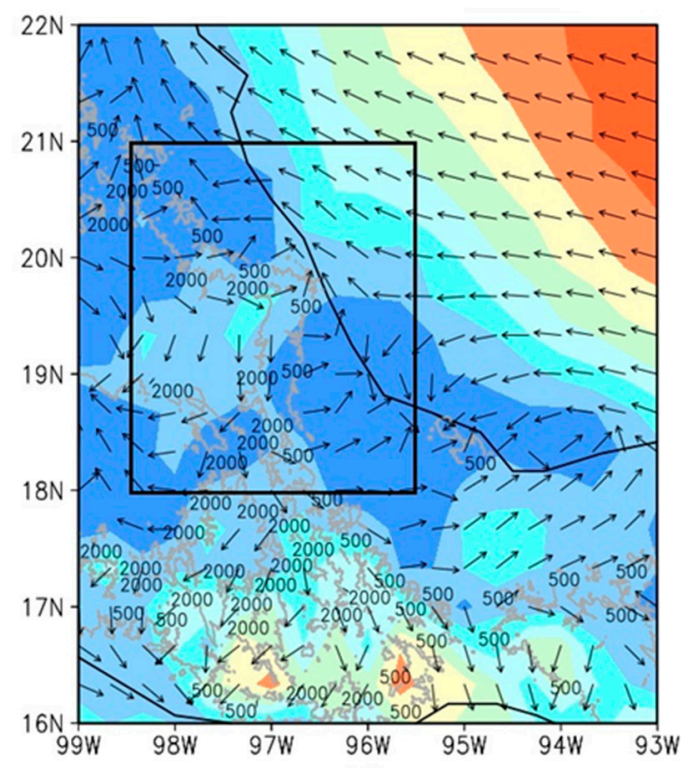

(c)

Figure 8. Average wind field $\left(\mathrm{m} \mathrm{s}^{-1}\right)$ at $10 \mathrm{~m}$ during the summer (May-October) for the (a) $04 \mathrm{LT}$, (b) $07 \mathrm{LT}$, and (c) $10 \mathrm{LT}$, from NARR reanalysis data for the period of 1979-2012. For clarity, the vectors correspond only to the wind direction; the magnitude is indicated by shaded. The contours of 500 and 2000 m.a.s.l. are shown.

The diurnal variability of the rainfall on the top of the mountain is similar to those observed on the slope, except that the values are lower. While the maximum value of precipitation on the mountain is $20 \mathrm{~mm} \mathrm{~h}^{-1}$ at $19 \mathrm{LT}$, on the top is about $16 \mathrm{~mm} \mathrm{~h}^{-1}$ at $01 \mathrm{LT}$ (Figure 7). 


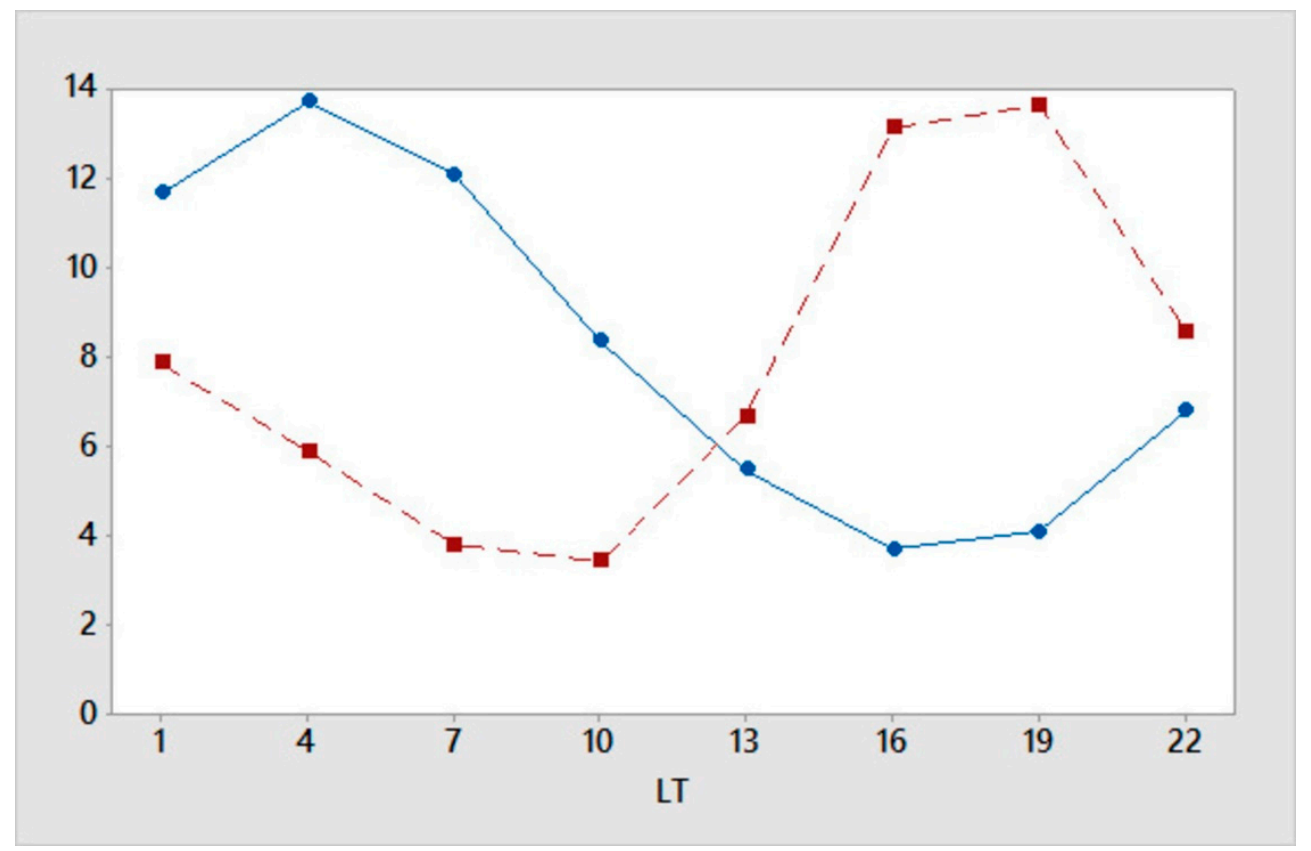

Figure 9. Variation of hourly mean rainfall $\left(\mathrm{mm} \mathrm{h}^{-1}\right)$ over VCZ for summer (May-October) in the continent (dotted) and the ocean (solid), considering the period 1998-2015. The domain considered is shown in the Figure 1a.

\section{Case Studies}

The measurement campaign performed from 28 June to 3 July 2015, brought detailed meteorological information in the VCZ (Figures 1a and 2). The behavior of the atmosphere was conditioned by local factors, since there were no striking synoptic scale disturbances. Observed cloud cover over the coastal region during the early morning hours seemed to be associated with the presence of a semi-permanent trough over the southwestern portion of the Gulf of Mexico. This trough weakened during the day and reactivated at night, also, when it was accompanied by a confluence line generated greater cloudiness which covered most of the region, as it occurred on 29 June and 1 July 2015 (not shown).

\subsection{Local Circulation from 29 June to 2 July}

On 29 June at 10 LT (Figure 10a), on the SVL the winds are observed from the ocean to the continent, associated with the sea breeze. In contrast, along the NVL the land breeze persists. Near the foothills of the SMO and over the TMVB headland, westward winds are likely associated with the valley breeze pattern (on the SMS slope are eastward). Around the top of the mountainous barriers, the wind is variable and it is not evident a clear pattern.

At noon and during the afternoon (13 LT and $16 \mathrm{LT}$ ), a significant change is observed due to the presence of the sea breeze which extends from the coast plains to the mountain ranges. Just before sunset (19 LT), the sea breeze still persists over most of the domain; except on northern flank and slope of the TMVB headland where westerly winds are observed against the prevailing easterlies. This is consistent with the presence of the westerly flow near the surface between the 16 and 19 LT in a point over the mountainous region of the $\mathrm{VCZ}$, which is associated with the development of a katabatic layer observed by Fitzjarrald [30]. On the other hand, on the top of mountains the winds present mainly a westerly component. 


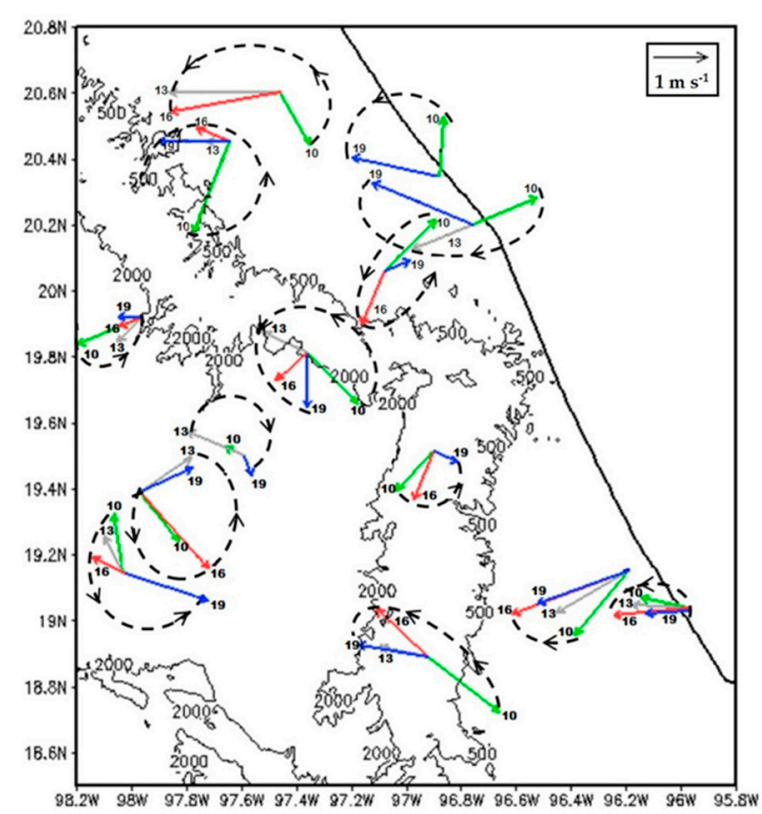

(a)

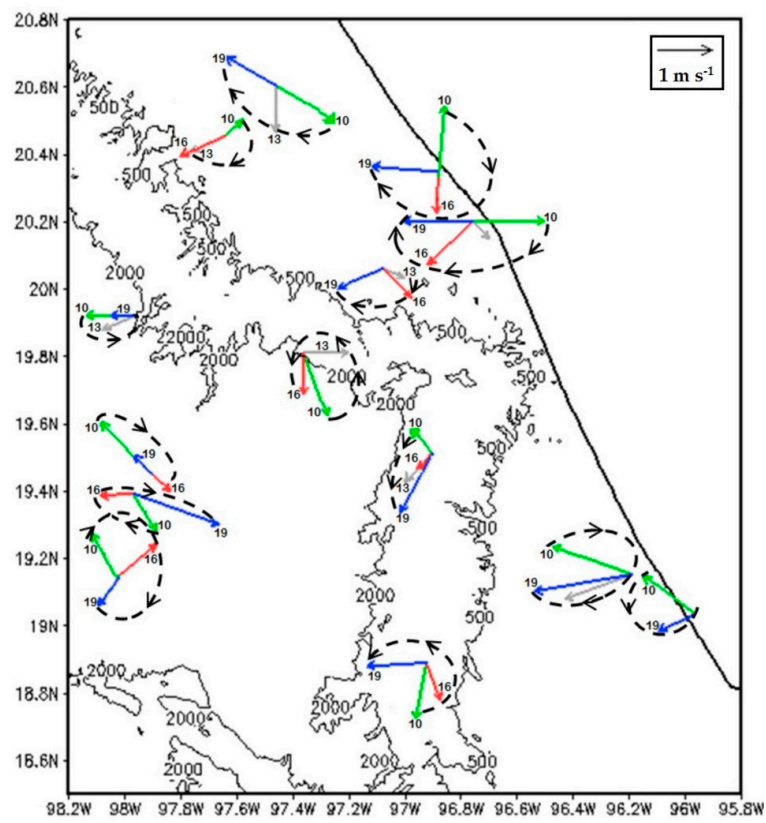

(c)

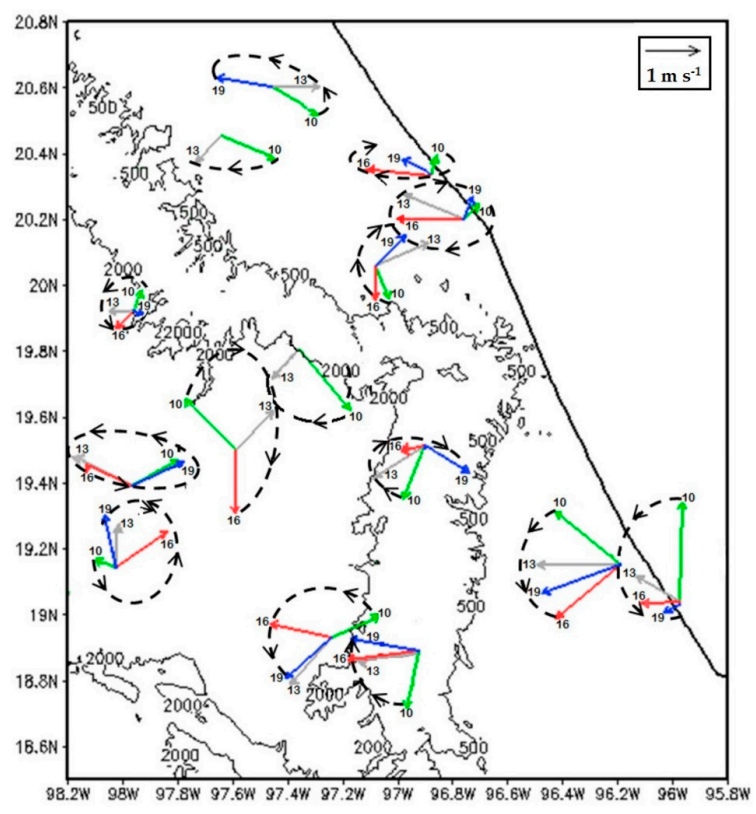

(b)

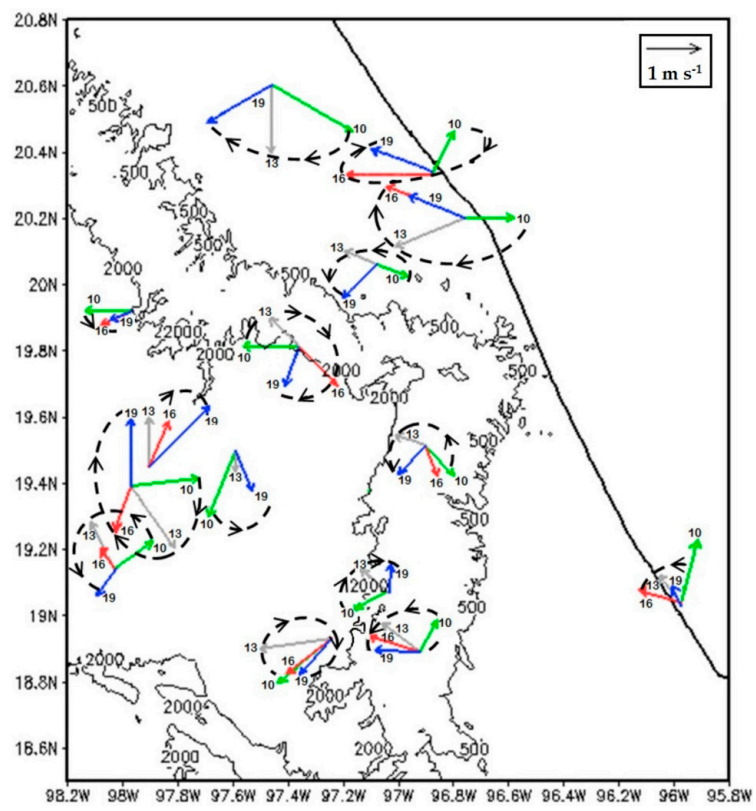

(d)

Figure 10. Surface wind observations $\left(\mathrm{m} \mathrm{s}^{-1}\right)$. The numbers at the end of the vectors indicate the local time, for the days (a) 29 June, (b) 30 June, (c) 1 July, and (d) 2 July 2015. The intensity scale is located in the upper left corner. The contours of 500 and 2000 m.a.s.l. are shown.

By 30 June at $10 \mathrm{LT}$, the winds are northeastward and northward over the northern and southern coastline respectively, associated with land breeze and northwesterly wind is observed over the NVL. The winds in a point on northern flank of the TMVB headland as well as over the SVL advance to the mountains, likely due to the valley breeze, induced by differential heating between the mountain ranges and plains. Over the slopes of the SMS and TMVB headland, the wind prevails parallel to the mountain ranges. During the afternoon (13-16 LT), easterly winds are observed over most of the focus domain, except in western portion of the top of the mountains where the easterly flow is interrupted. Furthermore, similar to what occurred on the previous day, at 19 LT on the northern flank and slope of the TMVB headland the winds move counter to easterly flow (Figure 10b). 
During the morning (10 LT) on 1 July (Figure 10c), the winds over the coastline show similar behavior to 29 June. In both days, the TMVB headland is the dividing line between the sea breeze in the southern and the land breeze on the northern portion. On the slope, as well as the top of mountains, it is difficult to observe a pattern. Between 13 and 16 LT over the VCZ, the winds show mainly northerly component. At 19 LT, easterly wind is observed at most surface observation sites related to sea breeze. Similar to previous days, over the top of mountainous barrier the wind is not coupled to the easterly flow.

On the morning of 2 July (Figure 10d), the wind shows westerly component over the coast plains and the hillside associated with the land breeze. Near the top of the mountains (around 2000 m.a.s.l.) easterly winds are observed and are probably related to the mountain breeze. Between 13 and $16 \mathrm{LT}$, the winds are associated with the sea breeze over most of the eastern portion of the focus domain. At $19 \mathrm{LT}$, easterly wind is observed on the mountains and their slopes. As previous days, on the top of the mountains ranges the wind shows a different pattern, which is probably related to other mechanisms over the Mexican Altiplano.

\subsection{Evening and Nocturnal Rainfall Episodes}

The following three episodes illustrate the role of the complex terrain in determining the location of afternoon rainfall.

On 29 June at $19 \mathrm{LT}$, the rainfall began near the top of the SMO and later increased in an area centered between $20^{\circ} \mathrm{N}$ and $20.2^{\circ} \mathrm{N}$. The enhancement of precipitation moved downhill toward the coastal plain (21 LT), reaching the coastline at $23 \mathrm{LT}$ with minor rainfall values compared with the observed at 21 LT (Figure 11). Probably, this contributes to the presence of nocturnal rainfall in the coastal region in the climate record [29]. According to Fitzjarrald [30] the katabatic outflow, consistent with the westerly winds over the TMVB headland observed at 19 LT on 29 June (Figure 10a), is associated with afternoon storms that generate a cool downdraft layer that acquires downslope momentum reaching the coastline $\left(19.14^{\circ} \mathrm{N}, 96.18^{\circ} \mathrm{W}\right)$ during the late afternoon $(18 \mathrm{LT})$. It is possible that these katabatic winds contribute to downhill movement of the precipitation towards Veracruz littoral. The results obtained by Sato et al. [13] for the Island of New Guinea also reported downstream propagation of the region of maximum rainfall, moving from the mountainous region towards the coastal zone. In the mountainous region of the U.S. Rockies, the rainfall propagates towards the central lowlands during the early morning hours [44]. Similar behavior is observed between the Yanshan-Taihangshan mountain range and adjacent plains in Northeastern China [23] and East of the Tibetan Plateau [10]. Over the Sierra Madre Occidental, convective systems (approximately $200 \mathrm{~km}$ in length) move from the sierra to the coast during the nocturnal hours [45].

On 30 June around 15-16 LT, the interaction of the moist wind flow with the mountainous barrier allowed the initiation of the rainfall over the mountain slopes; increasing quickly about $36 \mathrm{~mm} \mathrm{~h}^{-1}$ over an area centered between $19.6^{\circ} \mathrm{N}$ and $19.8^{\circ} \mathrm{N}$ (Figure 12a,b). This sequence resembles a pattern observed in other topographically similar places, such as those that occur with events of intense short-term rainfall called cloudbursts over the western region of Colombia [7] and over West Africa, where there is a rapid afternoon intensification of cloudiness and precipitation [43]. However, these locations lack the steady Trade Wind forcing characteristic of the Veracruz littoral. 


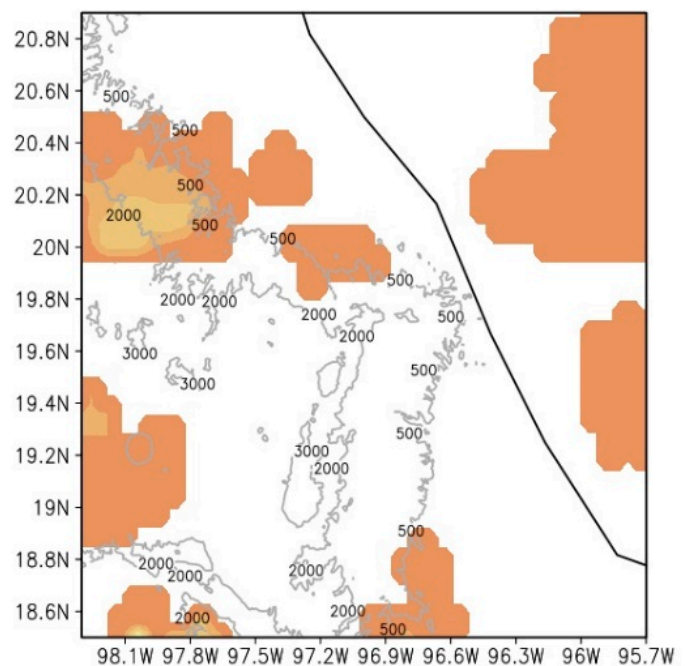

(a)

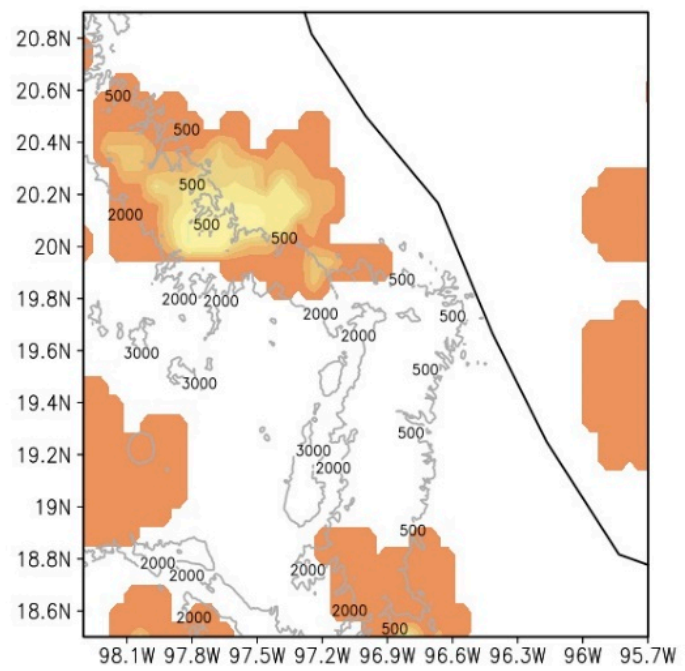

(b)
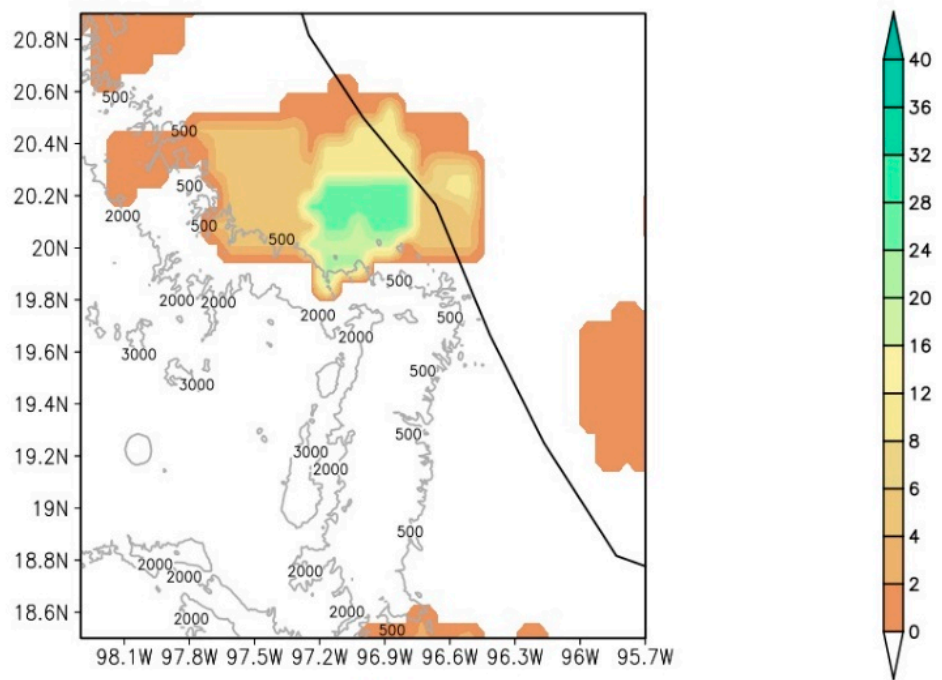

(c)

Figure 11. Rainfall $\left(\mathrm{mm} \mathrm{h}^{-1}\right)$ using CMORPH data (8-km spatial resolution) at (a) $19 \mathrm{LT}$, (b) $21 \mathrm{LT}$, and (c) 23 LT for the day 29 June 2015. The contours of 500 and 2000 m.a.s.l. are shown.

Moreover, over the northern flank of the TMVB headland (between $19.6^{\circ} \mathrm{N}$ and $19.8^{\circ} \mathrm{N}$ ) the rainfall propagated from the foothills to the coastline between 16 and 19 LT reaching the Gulf of Mexico by late afternoon (Figure 12), indicating that the sequence of events on 29 June was not unique. Furthermore, this propagation of the rainfall is consistent with the westerly winds observed at 19 LT on 30 June over on northern flank of the TMVB headland (Figure 10b). 


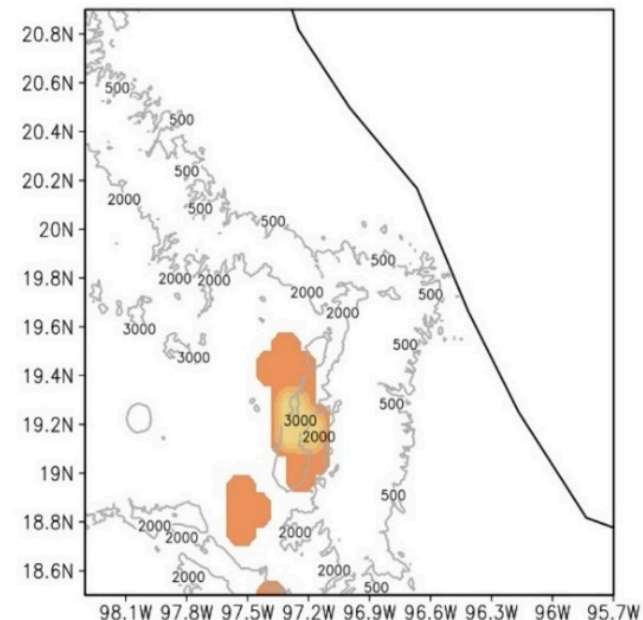

(a)

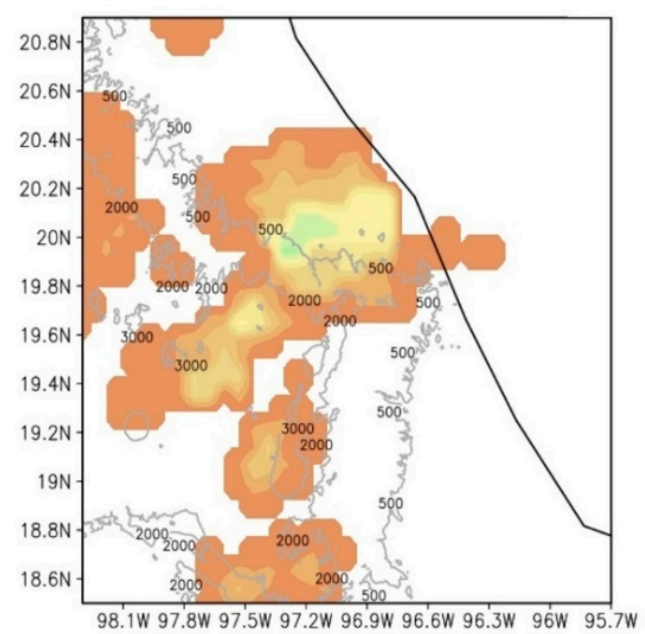

(c)

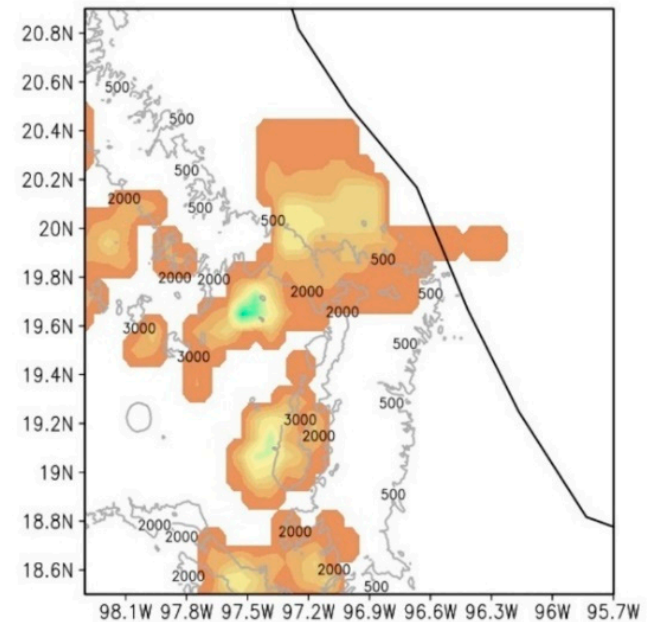

(b)

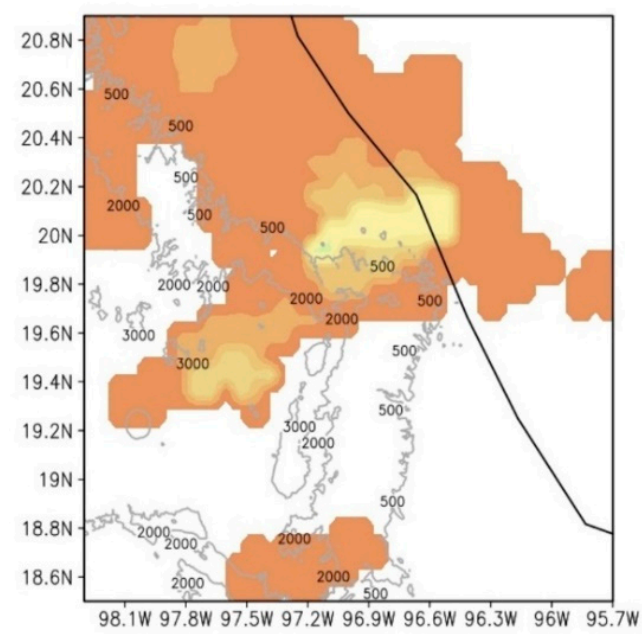

(d)

Figure 12. 8-km CMORPH (8-km spatial resolution) rainfall $\left(\mathrm{mm} \mathrm{h}^{-1}\right)$ at: (a) $15 \mathrm{LT}$, (b) $16 \mathrm{LT}$, (c) $17 \mathrm{LT}$, and (d) 19 LT by 30 June 2015. The contours of 500 and 2000 m.a.s.l. are shown.

On the other hand, on 1 July the rainfall values increased in the Gulf of Mexico during the early morning (Figure 13); from $12 \mathrm{~mm} \mathrm{~h}^{-1}$ at $01 \mathrm{LT}$ to $40 \mathrm{~mm} \mathrm{~h}^{-1}$ at $03 \mathrm{LT}$, disappearing at $05 \mathrm{LT}$. This is probably related with the convergence between the mean easterly flow and katabatic outflow from downdraft, as it was mentioned in the Section 4. 


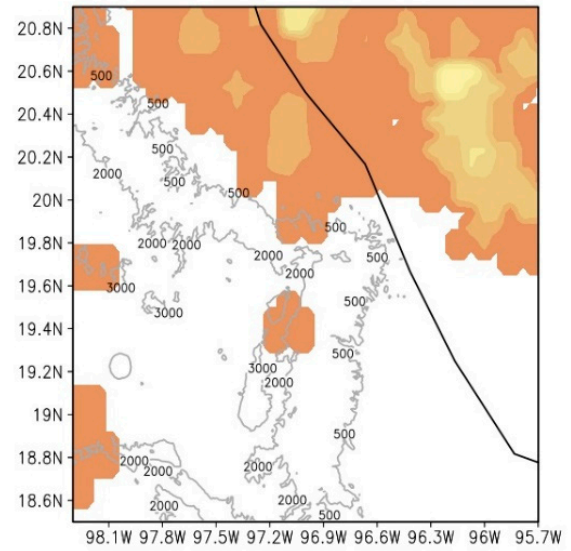

(a)

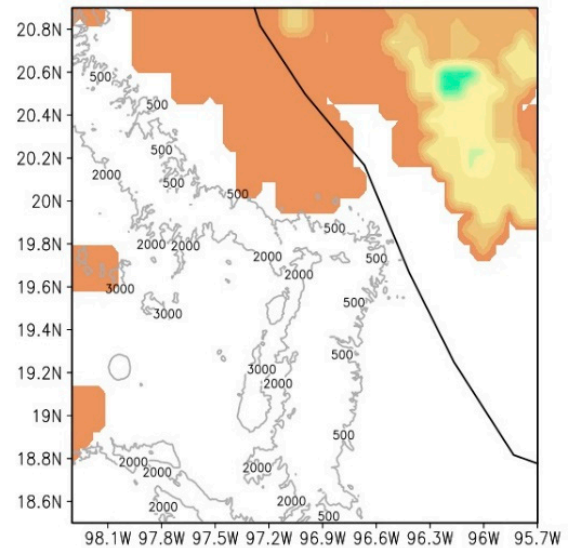

(b)

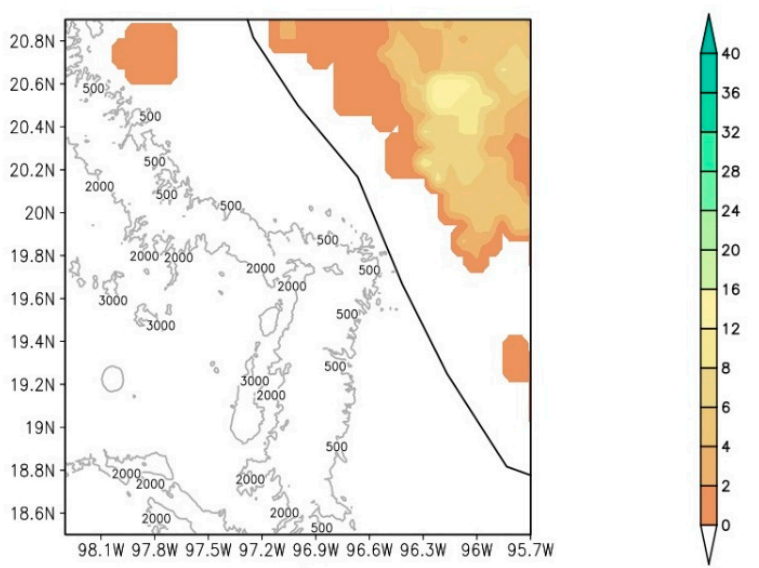

(c)

Figure 13. Precipitation $\left(\mathrm{mm} \mathrm{h}^{-1}\right)$ using CMORPH data (8-km spatial resolution) at (a) $01 \mathrm{LT}$, (b) $03 \mathrm{LT}$, and (c) 05 LT by 1 July 2015. The contours of 500 and 2000 m.a.s.l. are shown.

\section{Conclusions}

Rainfall in the VCZ, as in other regions of the tropics, is aligned over mountainous barriers. According to Garreaud and Wallace [2], in these regions the local circulation pattern is a dynamic forcing that favors the convection at certain time of the day when the atmospheric boundary layer reaches conditions of instability. In the absence of meso- or larger-scale meteorological disturbances, our results indicate that the presence of the trade winds is a fundamental mechanism to supply of moist wind to the region. However, the presence of this flow as well the local wind system may not be enough to explain the location and timing of the rainfall in the region. Therefore, the complex topography plays an essential role on the diurnal variations of the precipitation, since the initiation of the rainfall is not widespread over the VCZ. That is, the maximum of rainfall occurs a different hour on the plains, coast and top of mountains. The hourly mean precipitation increases between 16-19 LT over slopes and top of mountains, consistent with the increment of the intensity of the easterly flow that is forced to ascend over the mountain ranges. Over the plains, the occurrence of maximum precipitation is observed around 22-01 LT and is maintained until the early morning by mechanisms related to the convergence between the land breeze and trade winds.

The observational evidence obtained through the case studies, indicates that the modification of steady trade winds is mainly due to the presence of mountain ranges. That is, the sea breeze during the afternoon (Figure 10) presents an easterly component which is not fully normal to mountainous barrier, consistent with Tejeda et al. [29]. Moreover, on 29 and 30 June westerly winds from slope to plains are observed over the northern flank and slope of the TMVB headland. 
The presence of downslope winds has been documented by Fitzjarrald [30] and this study tries to relate these findings with the observed through the studies cases, suggesting that the westerly winds observed over the VCZ may be due to cool downdrafts which generate an afternoon katabatic wind. Furthermore, Fitzjarrald [30] found that along the Veracruz east-facing slope, katabatic winds begin in the afternoon and continue until the early hours of the subsequent day. This flow may contribute to the convergence between continental winds and easterly flow on the plains.

On the other hand, it is noted that the winds near the plateau along the TMVB are weakly coupled to the flow in the mountains, resulting a distinct climate regime compared to that along the east-facing slope.

The high time and space resolution of the CMORPH data allows to observe the propagation of the precipitation from slopes or foothills to plains, consistent with the observed westerly winds over the region from the measurement campaign.

The mechanisms that determine the propagation of the cores of maximum rainfall from the mountain to the coast over the VCZ remain open to question. The presence of a katabatic flow over the region reported by Fitzjarrald [30] is a plausible explanation. In other studies such as Bao et al. [10] and He and Zhang [23], the development of precipitation events during the maximum heating hours and later their propagation downhill to the plains have been related with the mid-tropospheric mean flow. Moreover, they suggest to examine the contributions of the cold-pool dynamics for explaining the movement of diurnal precipitation from high terrains to the plains.

More observational work is needed to explain these events, since this type of rainfall represents a unique hazard, as it can arrive unexpectedly during the early morning.

Author Contributions: Writing—original draft, M.P.-M.; Writing—review \& editing, A.T.-M. and D.R.F.

Funding: This research received no external funding.

Acknowledgments: This work is part of Project CONACyT-UV (CB2012-183040) "Interacción superficie/atmósfera en la zona montañosa central de la vertiente del Golfo de México: observaciones y modelación a alta resolución". We are grateful for support during data collection of the colleagues Antonio Luna Díaz Peón, Carlo Alberto Domínguez Eusebio, Adrián Álvarez Pérez, and Aranza Baruch Vera. Special thanks to Jaime S. Hernández Alfaro.

Conflicts of Interest: The authors declare no conflict of interest.

\section{Appendix A}

Table A1. Estimates of the TCs contribution to annual and seasonal mean rainfall, over regions that include the VCZ. Values reported by different authors.

\begin{tabular}{|c|c|c|c|c|}
\hline Authors & $\begin{array}{c}\text { Rodgers et al. } \\
\text { (2001) }\end{array}$ & $\begin{array}{c}\text { Jiang and Zipser } \\
(2009)\end{array}$ & Prat and Nelson (2013) & $\begin{array}{l}\text { Khouakhi et al. } \\
\text { (2017) }\end{array}$ \\
\hline $\begin{array}{l}\text { Contribution } \\
\text { Month }\end{array}$ & $\begin{array}{l}\text { to annual mean } \\
\text { rainfall }\end{array}$ & $\begin{array}{l}\text { to annual mean } \\
\text { rainfall }\end{array}$ & to annual mean rainfall & $\begin{array}{c}\text { to seasonal mean } \\
\text { rainfall }\end{array}$ \\
\hline DEC & $0 \%$ & $0 \%$ & $0 \%$ & \\
\hline JAN & $0 \%$ & $0 \%$ & $0 \%$ & $0 \%$ \\
\hline FEB & $0 \%$ & $0 \%$ & $0 \%$ & \\
\hline MAR & $0 \%$ & $0 \%$ & $0 \%$ & \\
\hline APR & $0 \%$ & $0 \%$ & $0 \%$ & $3 \%$ \\
\hline MAY & $0 \%$ & $0 \%$ & $1 \%$ & \\
\hline JUN & $1 \%$ & $2 \%$ & $2 \%$ & \\
\hline JUL & $3 \%$ & $3 \%$ & $2 \%$ & $15 \%$ \\
\hline AUG & $5 \%$ & $10 \%$ & $4 \%$ & \\
\hline SEP & $6 \%$ & $20 \%$ & $11 \%$ & \\
\hline OCT & $6 \%$ & $7 \%$ & $6 \%$ & $20 \%$ \\
\hline $\mathrm{NOV}$ & $4 \%$ & $2 \%$ & $2 \%$ & \\
\hline Focus domain & $\begin{array}{c}100^{\circ} \mathrm{W}-50^{\circ} \mathrm{W} \\
5^{\circ} \mathrm{N}-35^{\circ} \mathrm{N}\end{array}$ & $\begin{array}{c}85^{\circ} \mathrm{W}-20^{\circ} \mathrm{W} \\
5^{\circ} \mathrm{N}-30^{\circ} \mathrm{N}\end{array}$ & $\begin{array}{c}130^{\circ} \mathrm{W}-50^{\circ} \mathrm{W} \\
0^{\circ} \mathrm{N}-50^{\circ} \mathrm{N}\end{array}$ & Global \\
\hline Period & $\begin{array}{c}1988,1989, \text { and } \\
1991-1998\end{array}$ & $\begin{array}{l}1998-2000 \text { and } \\
2002-2006\end{array}$ & 1998-2009 & $\begin{array}{c}\text { Data between } 1970 \\
\text { and } 2014\end{array}$ \\
\hline Data & $\begin{array}{l}\text { SSM/I (Special } \\
\text { Sensor Microwave } \\
\text { Imager)-derived }\end{array}$ & $\begin{array}{l}\text { Tropical Rainfall } \\
\text { Measuring Mission } \\
\text { (TRMM) }\end{array}$ & $\begin{array}{l}\text { Tropical Rainfall Measuring } \\
\text { Mission (TRMM) } \\
\text { Multi-satellite Precipitation } \\
\text { Analysis (TMPA) product 3B42 }\end{array}$ & $\begin{array}{c}18,607 \text { global rain } \\
\text { gauges }\end{array}$ \\
\hline
\end{tabular}




\section{References}

1. Houze, R.A.; Geotis, S.G.; Marks, F.D., Jr.; West, A.K. Winter monsoon convection in the vicinity of north Borneo. Part I: Structure and time variation of the clouds and precipitation. Mon. Weather Rev. 1981, 109, 1595-1614. [CrossRef]

2. Garreaud, R.; Wallace, J.M. The diurnal march of convective cloudiness over the Americas. Mon. Weather Rev. 1997, 125, 3157-3171. [CrossRef]

3. Dai, A.; Giorgi, F.; Trenberth, K.E. Observed and model-simulated diurnal cycles of precipitation over the contiguous United States. J. Geophys. Res. Atmos. 1999, 104, 6377-6402. [CrossRef]

4. Ohsawa, T.; Ueda, H.; Hayashi, T.; Watanabe, A.; Matsumoto, J. Diurnal variations of convective activity and rainfall in tropical Asia. J. Meteorol. Soc. Jpn. Ser. II 2001, 79, 333-352. [CrossRef]

5. Yang, G.-Y.; Slingo, J. The diurnal cycle in the tropics. Mon. Weather Rev. 2001, 129, 784-801. [CrossRef]

6. Sorooshian, S.; Gao, X.; Hsu, K.; Maddox, R.; Hong, Y.; Gupta, H.V.; Imam, B. Diurnal variability of tropical rainfall retrieved from combined GOES and TRMM satellite information. J. Clim. 2002, 15, 983-1001. [CrossRef]

7. Mapes, B.E.; Warner, T.T.; Xu, M.; Negri, A.J. Diurnal patterns of rainfall in northwestern South America. Part I: Observations and context. Mon. Weather Rev. 2003, 131, 799-812. [CrossRef]

8. Yang, S.; Smith, E.A. Mechanisms for diurnal variability of global tropical rainfall observed from TRMM. J. Clim. 2006, 19, 5190-5226. [CrossRef]

9. Kikuchi, K.; Wang, B. Diurnal precipitation regimes in the global tropics. J. Clim. 2008, 21, $2680-2696$. [CrossRef]

10. Bao, X.; Zhang, F.; Sun, J. Diurnal variations of warm-season precipitation east of the Tibetan Plateau over China. Mon. Weather Rev. 2011, 139, 2790-2810. [CrossRef]

11. Huang, W.-R.; Wang, S.-Y. Impact of land-sea breezes at different scales on the diurnal rainfall in Taiwan. Clim. Dyn. 2014, 43, 1951-1963. [CrossRef]

12. Lee, M.-I.; Schubert, S.D.; Suarez, M.J.; Held, I.M.; Kumar, A.; Bell, T.L.; Schemm, J.-K.E.; Lau, N.-C.; Ploshay, J.J.; Kim, H.-K. Sensitivity to horizontal resolution in the AGCM simulations of warm season diurnal cycle of precipitation over the United States and northern Mexico. J. Clim. 2007, 20, 1862-1881. [CrossRef]

13. Sato, T.; Miura, H.; Satoh, M.; Takayabu, Y.N.; Wang, Y. Diurnal cycle of precipitation in the tropics simulated in a global cloud-resolving model. J. Clim. 2009, 22, 4809-4826. [CrossRef]

14. Dirmeyer, P.A.; Cash, B.A.; Kinter, J.L.; Jung, T.; Marx, L.; Satoh, M.; Stan, C.; Tomita, H.; Towers, P.; Wedi, N. Simulating the diurnal cycle of rainfall in global climate models: Resolution versus parameterization. Clim. Dyn. 2012, 39, 399-418. [CrossRef]

15. Nikulin, G.; Jones, C.; Giorgi, F.; Asrar, G.; Büchner, M.; Cerezo-Mota, R.; Christensen, O.B.; Déqué, M.; Fernandez, J.; Hänsler, A. Precipitation climatology in an ensemble of CORDEX-Africa regional climate simulations. J. Clim. 2012, 25, 6057-6078. [CrossRef]

16. Wallace, J.M. Diurnal variations in precipitation and thunderstorm frequency over the conterminous United States. Mon. Weather Rev. 1975, 103, 406-419. [CrossRef]

17. Oki, T.; Musiake, K. Seasonal change of the diurnal cycle of precipitation over Japan and Malaysia. J. Appl. Meteorol. 1994, 33, 1445-1463. [CrossRef]

18. Chen, T.-C.; Yen, M.-C.; Hsieh, J.-C.; Arritt, R.W. Diurnal and seasonal variations of the rainfall measured by the automatic rainfall and meteorological telemetry system in Taiwan. Bull. Am. Meteorol. Soc. 1999, 80, 2299-2312. [CrossRef]

19. Kishtawal, C.; Krishnamurti, T. Diurnal variation of summer rainfall over Taiwan and its detection using TRMM observations. J. Appl. Meteorol. 2001, 40, 331-344. [CrossRef]

20. Mori, S.; Jun-Ichi, H.; Tauhid, Y.I.; Yamanaka, M.D.; Okamoto, N.; Murata, F.; Sakurai, N.; Hashiguchi, H.; Sribimawati, T. Diurnal land-sea rainfall peak migration over Sumatera Island, Indonesian Maritime Continent, observed by TRMM satellite and intensive rawinsonde soundings. Mon. Weather Rev. 2004, 132, 2021-2039. [CrossRef]

21. Kousky, V.; Janowiak, J.; Joyce, R. The Diurnal Cycle of Precipitation over the Americas based on CMORPH. J. Geophys. Res. Atmos. 2005, 110. [CrossRef]

22. Qian, J.-H. Why precipitation is mostly concentrated over islands in the Maritime Continent. J. Atmos. Sci. 2008, 65, 1428-1441. [CrossRef] 
23. He, H.; Zhang, F. Diurnal variations of warm-season precipitation over northern China. Mon. Weather Rev. 2010, 138, 1017-1025. [CrossRef]

24. Singh, P.; Nakamura, K. Diurnal variation in summer precipitation over the central Tibetan Plateau. J. Geophys. Res. Atmos. 2009, 114. [CrossRef]

25. Vidal, R. Las Regiones Climáticas de México: Temas Selectos de Geografía de México; Instituto de Geografía, UNAM: Ciudad de México, México, 2005.

26. Ruiz-Barradas, A.; Tejeda-Martínez, A.; Miranda-Alonso, S.; Flores-Zamudio, R.H. Climatología. In Atlas del Patrimonio Natural, Histórico y Cultural de Veracruz; Florescano, E., Ortíz-Escamilla, O., Eds.; Gobierno del Estado de Veracruz y Universidad Veracruzana: Veracruz, Mexico, 2010; pp. 203-226.

27. Jáuregui, E.; Soto, C. La Vertiente del Golfo de México, Algunos Aspectos Fisiográficos y Climáticos. BoletÍN Inst. Geogr. ÍA 1975, 6, 37-45.

28. Mosiño, P.; García, E. The climate of Mexico. Climates of North America. World Surv. Climatol. 1974, 11, 345-404.

29. Tejeda, A.; Méndez Pérez, I.R.; Utrera, A.; García Tello, L.G.; Mendoza, V.M. Circulación local y ascenso de aire en un sitio costero y tropical al pie de la montaña. El Clima Entre El Mar Y La Montaña 2004, 4, 145-154.

30. Fitzjarrald, D.R. Slope winds in Veracruz. J. Clim. Appl. Meteorol. 1986, 25, 133-144. [CrossRef]

31. Nesbitt, S.W.; Zipser, E.J. The diurnal cycle of rainfall and convective intensity according to three years of TRMM measurements. J. Clim. 2003, 16, 1456-1475. [CrossRef]

32. Joyce, R.J.; Janowiak, J.E.; Arkin, P.A.; Xie, P. CMORPH: A method that produces global precipitation estimates from passive microwave and infrared data at high spatial and temporal resolution. J. Hydrometeorol. 2004, 5, 487-503. [CrossRef]

33. Mesinger, F.; DiMego, G.; Kalnay, E.; Mitchell, K.; Shafran, P.C.; Ebisuzaki, W.; Jović, D.; Woollen, J.; Rogers, E.; Berbery, E.H. North American regional reanalysis. Bull. Am. Meteorol. Soc. 2006, 87, 343-360. [CrossRef]

34. DeHart, J.C.; Houze, R.A., Jr. Orographic modification of precipitation processes in Hurricane Karl (2010). Mon. Weather Rev. 2017, 145, 4171-4186. [CrossRef]

35. Breña-Naranjo, J.A.; Pedrozo-Acuña, A.; Pozos-Estrada, O.; Jiménez-López, S.A.; López-López, M.R. The contribution of tropical cyclones to rainfall in Mexico. Phys. Chem. Earth Parts A/B/C 2015, 83, 111-122.

36. Jiang, H.; Zipser, E.J. Contribution of tropical cyclones to the global precipitation from eight seasons of TRMM data: Regional, seasonal, and interannual variations. J. Clim. 2010, 23, 1526-1543. [CrossRef]

37. Prat, O.P.; Nelson, B.R. Mapping the world's tropical cyclone rainfall contribution over land using the TRMM Multi-satellite Precipitation Analysis. Water Resour. Res. 2013, 49, 7236-7254. [CrossRef]

38. Rodgers, E.B.; Adler, R.F.; Pierce, H.F. Contribution of tropical cyclones to the North Atlantic climatological rainfall as observed from satellites. J. Appl. Meteorol. 2001, 40, 1785-1800. [CrossRef]

39. Khouakhi, A.; Villarini, G.; Vecchi, G.A. Contribution of tropical cyclones to rainfall at the global scale. J. Clim. 2017, 30, 359-372. [CrossRef]

40. Malkus, J.S. On the Structure of the Trade Wind Moist Layer; Massachusetts Institute of Technology and Woods Hole Oceanographic Institution: Cambridge, MA, USA, 1958.

41. Malkus, J.S. On the maintenance of the trade winds. Tellus 1956, 8, 335-350. [CrossRef]

42. Satomura, T. Diurnal variation of precipitation over the Indo-China Peninsula. J. Meteorol. Soc. Jpn. Ser. II 2000, 78, 461-475. [CrossRef]

43. Reed, R.J.; Jaffe, K.D. Diurnal variation of summer convection over West Africa and the tropical eastern Atlantic during 1974 and 1978. Mon. Weather Rev. 1981, 109, 2527-2534. [CrossRef]

44. Jiang, X.; Lau, N.C.; Klein, S.A. Role of eastward propagating convection systems in the diurnal cycle and seasonal mean of summertime rainfall over the US Great Plains. Geophys. Res. Lett. 2006, 33. [CrossRef]

45. Nesbitt, S.W.; Gochis, D.J.; Lang, T.J. The diurnal cycle of clouds and precipitation along the Sierra Madre Occidental observed during NAME-2004: Implications for warm season precipitation estimation in complex terrain. J. Hydrometeorol. 2008, 9, 728-743. [CrossRef]

(C) 2019 by the authors. Licensee MDPI, Basel, Switzerland. This article is an open access article distributed under the terms and conditions of the Creative Commons Attribution (CC BY) license (http://creativecommons.org/licenses/by/4.0/). 